\title{
Histomorphometric changes in the gill of Clavias gariepinus exposed to acute concentrations of chlorpyrifos
}

\author{
OMIRINDE, J. O ${ }^{1 *}$., AUDU, B. S $^{2}$, MOHAMMED, O. M. ${ }^{2}$ and \\ GOSOMJI, I. J. ${ }^{1}$
}

\begin{abstract}
${ }^{1}$ Department of Veterinary Anatomy, Faculty of Veterinary Medicine, University of Jos, P.M.B 2084 Jos, Plateau State Nigeria, Post code 930001, Plateau, Nigéria

${ }^{2}$ Applied Hydrobiology and Fisheries Unit, Department of Zoology, Faculty of Natural Sciences, University of Jos, P.M.B 2084 Jos, Plateau State Nigeria, Post code 930001, Plateau, Nigéria

*E-mail: omirindejamiu@yahoo.com
\end{abstract}

\begin{abstract}
Introduction: Chlorpyrifos is an agrochemical pesticide of fame that is commonly used by farmers to control pests. This chemical may become harmful to fish when washed into waterways leading to aquatic environment. This study investigates the histo-morphometric changes in the gills of African Catfish Clarias gariepinus exposed to acute toxic concentrations of chlorpyrifos. Materials and Methods: Clarias gariepinus fingerlings (weight $7.28 \pm 0.03 \mathrm{~g}$ and length $4.82 \pm 0.06 \mathrm{~cm}$ ) were exposed to grades of $(6.25,12.5,25,50 \mathrm{and} 100 \mu \mathrm{ml} / \mathrm{L}$ ) chlorpyrifos in solution. The 96 hour $\mathrm{LC}_{50}$ value of chlorpyrifos was found to be $160 \mu \mathrm{ml} / \mathrm{L}$. Results: The grades of chlorpyrifos induced several gill histo-architectural damages such as: moderate to severe gill epithelia sloughing, primary and secondary lamellar hyperplasia and central veinous congestion in the parenchyma with pronounced severity in fish exposed to higher concentrations. Similarly, the gill morphometrics (secondary lamellar length, width, interlamellar distance and surface area) were markedly altered by the graded concentrations of chlorpyrifos. Conclusion: Chlorpyrifos appears to be very toxic to fish and therefore, its use near fish farms or in areas close to aquatic environments should be discouraged.
\end{abstract}

Keywords: chlorpyrifos, Clarias gariepinus, histomorphometrics, histoarchitecture, gill.

\section{Introduction}

Chlorpyrifos is a non-systemic organophosphate agrochemical pesticide of fame that is commonly used by farmers to control pests. It is commonly applied as a foliar spray or by direct incorporation into the soil before planting (WATTS, 2013; DEB and SUCHISMITA, 2013). This chemical may become harmful especially to fish when washed into other components of the ecosystem like the waterways leading to aquatic environment. It is worthy of mention that the presence of this chemical at low concentrations has been reported to have toxically induced morphological alterations in the tissues of fish and birds (CHAKRABURTHY and KONAR, 1974; MATHUR, AGARWAL and RANA, 1981; VIJAYALAKSHMI and TILAK, 1996).

Investigation into the effects of chlorpyrifos on fish has been found to have diagnostic significance that can be used to predict probable mechanisms of its toxicity in human population. (DEB and SUCHISMITA, 2013). Sharbidre, Metkari and Patode (2011) and Deb and Suchismita (2013) observed that chlorpyrifos has three main modes of actions following its absorption through ingestion, inhalation and skin penetration. It could act by inhibiting enzyme acetylcholinesterase required for the control of nervous stimulation thereby resulting in overstimulation of the nervous system with attendant clinical signs like increased secretions, sensory and specific behavioural disturbances that include gulping, increased opercular movement, erractic swimming and subsequent lethargy in intoxicated fish. In addition, chlorpyrifos may cause generation of reactive oxygen species (ROS), which may inturn induce oxidative stress that is typified by significant decrease in antioxidant enzymes [glutathione (GSH), catalase (CAT) and glutathione $S$ transferase (GST)] activities which are essential for cellular antioxidant defence mechanisms (SAYEED, PARVEZ, PANDEY et al., 2003; DEB and SUCHISMITA, 2013). It is also reported to be a potent endocrine disruptors and capable of inhibiting the synthesis and metabolism of testosterone, oestradiol and thyroid hormones (DEB and SUCHISMITA, 2013)

The gill is structurally made up of primary lamellae which are leaf like structures with a centrally located rod-like supporting axis (BUTCHIRAM et al., 2009). A row of secondary gill lamellae (respiratory lamellae) laterally emanates from each side of the interbranchial septum of the former (BUTCHIRAM et al., 2009; SANTOS, GOMES, PASSOS et al., 2011). The surfaces of the secondary lamellae are covered with simple squamous epithelial cells separated by mucous cells with several blood vessels extending into each of the secondary gill filaments (BUTCHIRAM et al., 2009; SANTOS, GOMES, PASSOS et al., 2011). Two adjacent secondary lamellae of the gill are separated by a region referred to as interlamellar region (PATNAIK, HONGRAY, THERESIA et al., 2011)

Gills in fishes partake in diverse functions such as respiration, osmoregulation and excretion and remain the bordering part of the fish and external environment (POLEKSIC and MITROVIC-TUTUNDZIC, 1994; SANTOS, GOMES, PASSOS et al., 2011). This predisposes it to being the first sensitive part to any chemical or physical alterations in the aquatic environment (POLEKSIC and MITROVIC-TUTUNDZIC, 
1994; CAMARGO and MARTINEZ, 2007). This is in-turn mainly due to the large surface area of the respiratory gill epithelium and the concomitant high perfusion rate that facilitates the entry of pollutants into it (POLEKSIC and MITROVICTUTUNDZIC, 1994; REDDY and WASKALE, 2013). In line with this, the histo-architectural integrity of the gill remained a very essential morphological index to be evaluated for the health of fish exposed to contaminants in both laboratory and field studies (HINTON, BAUMANN, GARDNER et al., 1992; TEH, ADAMS and HINTON, 1997; THOPHON, KRUATRACHUE, UPATHAM et al., 2003).

Clarias gariepinus also known as African catfish belongs to the family Clariidae (FOOD..., 2016). It is a freshwater fish, popularly cultured by fish farmers in Africa owing to its rapid growth rate, high stocking-density, increased consumer suitability and superior resistance to poor water quality (AKINWOLE and FATUROTI, 2007; KARAMI, CHRISTIANUS, ISHAK et al., 2010). It is therefore a fish of choice for research purposes (MAHMOUD, MEKKAWY and SAYED, 2009). Considerable investigations on the use of C.gariepinus to study chlorpyrifos toxicity attracted many workers with more focus on the deleterious effects of chlorpyrifos on the the haematological and biochemical profiles (OKECHUKWU, AUTA and BALOGUN, 2007; NWANI, UGWU, OKEKE et al., 2013; NWANI, IVOKE, OKECHUKWU et al., 2013; SAMAJDAR and MANDAL, 2015 ) and to some extent histological alterations to the gill (DEVI and MISHRA, 2013). However, there is paucity of report on the histio-morphometric changes on the gill of African Catfish Clarias gariepinus exposed to acute toxic concentrations of chlorpyrifos; hence this study seeks to investigate the possibility.

\section{Materials and Methods}

\subsection{Experimental fish}

Clarias gariepinus fingerlings of mean weight $(7.37 \pm 1.40 \mathrm{~g})$ and mean length $(4.85 \pm 0.06 \mathrm{~cm})$ were collected from a commercial fish farm (Global Aquaculture and Allied Ventures ${ }^{\circledR}$ ) in Jos, Plateau State, Nigeria. They were acclimatized in the Fishery and Hydrobiology Laboratory of the Zoology Department, University of Jos, Jos, Nigeria for a period of 7 days in two circular plastic containers of 50 litres volume containing clean dechlorinated tap water at $\mathrm{pH} 7.1$; oxygen $88-95 \%$ saturation; temperature $27-28{ }^{\circ} \mathrm{C}$; carbondioxide concentration $6-8 \mathrm{mg} / \mathrm{L}$, total alkalinity $85-95 \mathrm{mg} / \mathrm{L}$ and photoperiod 12:12 light: dark. The fish were fed twice daily on commercially prepared fish feed (Vital feed ${ }^{\circledR}$, Nigeria) before the commencement of experiment.

\subsection{Experimental toxicant (Chlorpyrifos)}

The test material Termocot ${ }^{\circledR}$ is an emulsified concentrate manufactured by Gujarat Ltd, India.

\subsection{Experimental design}

The static renewal bioassay technique of EPA (U.S. ENVIRONMENTAL..., 1985) was used during the experiment. After pilot tests, the toxicant concentration $100 \mu \mathrm{ml} / \mathrm{L}$ of chlorpyrifos was considered for serial dilution as the least tolerance test concentrations and from which subsequent concentrations of $50,25,12.5,6.25 \mu \mathrm{ml} / \mathrm{L}$ were obtained through serial dilutions. Based on the toxicant concentrations, the acclimatized C.gariepinus were randomly divided into six groups ( 10 fish per each) of two replicates; Group A: - control (0.00 ml $\backslash \mathrm{L}$ of chlorpyrifos), Groups B- F: with chlorpyrifos $(6.25,12.5,25,50$ and $100 \mathrm{ml} / \mathrm{L}$ respectively). The duration of the acute exposure to chlorpyrifos was 96 hours.

\subsection{Histopathological preparations}

At end of the experiment, fish were anesthetized using benzocaine $(0.1 \mathrm{~g} / \mathrm{L})$ and subsequently sacrificed by cervical section. Gills tissues were then excised, rinsed in physiological saline and fixed in aqueous Bouin's fluid. The fixed tissues were then dehydrated in ascending grades of alcohol concentrations, cleared in xylene, embedded in paraffin and sectioned at $5 \mathrm{~mm}$. Sectioned tissues were then stained with haematoxylin-eosin (HE) and examined with light microscope (Olympus, China) at X100 magnification. In addition histio-morphometric measurements (Secondary lamellar width, length, surface area and Inter-lamellar distance) were determined using 10 randomly selected sections of 10 fish from each experimental group using Motic image plus 2.0 (Motic Asia, Hongkong) software.

\subsection{Statistical analysis}

Data obtained were expressed as mean \pm SE. One way analysis of variance (ANOVA) was used to evaluate significant difference between groups and the values of $p<0.05$ were considered significant. A Turkey post ad-hoc test was used to evaluate significant difference between groups using GraphPad Prism 4.0 (GraphPad software Inc., California, USA.) statistical package.

\section{Results}

\subsection{Gill histopathology}

The gills of the control fish is characterized by primary filament with a centrally located rod-like supporting axis with rows of secondary gill lamellae laterally emanating from each side of the interbranchial septum of the primary filament (Figure 1A). The surfaces of the secondary lamellae are covered with epithelial cells and two neighboring secondary lamellae are separated by water channel or interlamellar region. However, chlorpyrifos exposed groups of fish displayed various degree of histoarchitectural damages such as apical clubbing and rupturing of the secondary lamellae, gill filament vascular congestion, hypertrophy and hyperplasia of the lamellar epithelial cells. The severity of the gill histomorphological alterations seems to be dose- dependent (Figure lB-F).

\subsection{Gill histomorphometry}

The effects of chlorpyrifos intoxication on the gill morphometrics in C.gariepinus are presented in Table 1.

\subsection{SLW (Secondary Lamellar Width)}

Secondary lamellar width is the distance between two edges of a lamella base. It is a parallel distance to the filament. The SLW of chlorpyrifos intoxicated-C.gariepinus gill showed significant enlargement $(\mathrm{p}<0.05)$ with increased concentrations of chlorpyrifos exposure. There was no significant $(\mathrm{p}>0.05)$ SLW increment at doses $6.25,12.5,25$ and $100(\mu \mathrm{ml} / \mathrm{L})$ relative to others. However, there was a marked significant increment $(\mathrm{p}<0.05)$ in SLW at the highest dose of the toxicant (100 $\mu \mathrm{ml} / \mathrm{L})$ relative to other groups. 


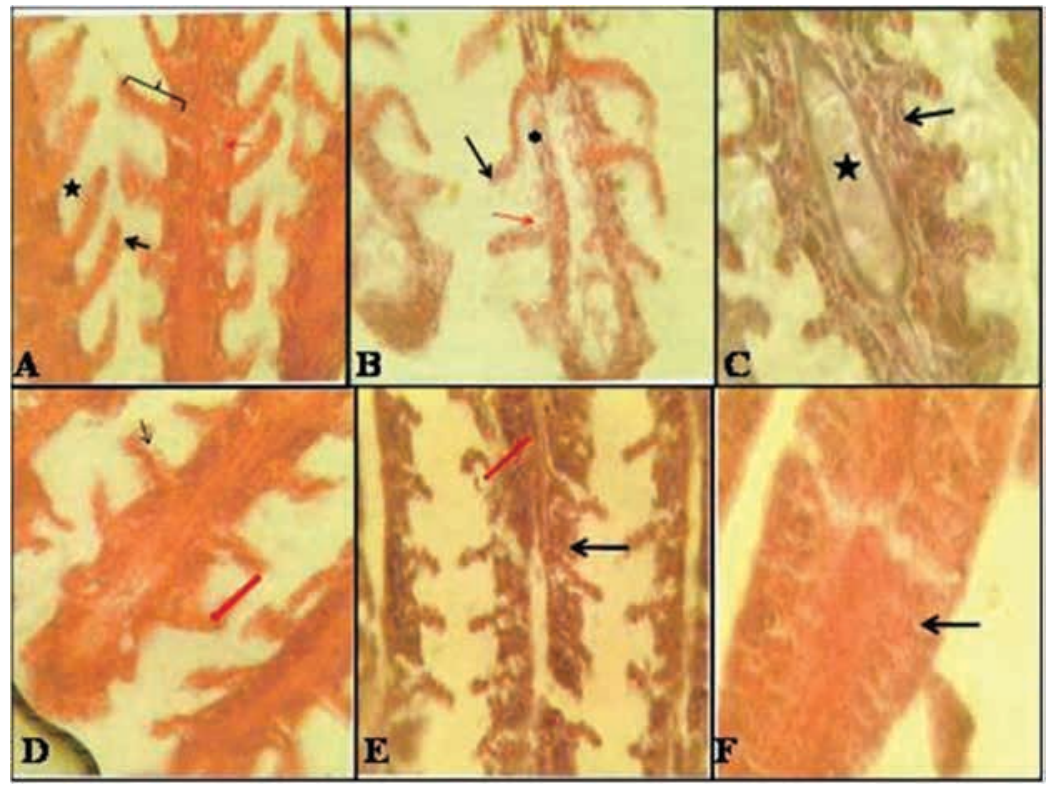

Figure 1. The photomicrographs of the gills of C.gariepinus exposed to grades of chlorpyrifos (CF). (A) Control ( $0.00 \mathrm{Ml} / \mathrm{L}$ of CF): a normal gill showing the primary gill filament (red arrow), secondary lamellae (brace), epithelial cells of the secondary lamellae (black arrow), the inter-lamellae space or water channel (star); (B) $6.25 \mu \mathrm{ml} / \mathrm{L}$ : apical clubbing of the secondary lamellae (black arrow), diffuse rupturing of few secondary lamellae (red arrow), generalized thinning of the primary gill filament (asterick); (C) 12.5 $\mu \mathrm{ml} / \mathrm{L}$ : congested gill filament vessel (star) and hypertrophy of lamellar epithelium (arrow); (D) $25 \mu \mathrm{ml} / \mathrm{L}$ : generalized lamellar epithelial cell rupture (black arrow) and apical clubbing of the secondary lamellae (red arrow); (E) $50 \mu \mathrm{ml} / \mathrm{L}$ : severe lamellar epithelial cell rupture (red arrow) and lamellar epithelial hyperplasia (black arrow); (F) $100 \mu \mathrm{ml} / \mathrm{L}$ : severe lamellar epithelial hyperplasia with total occlusion of water channels (arrow). Magnification xl00.

Table 1. The gill histomorphometrics of Clarias gariepinus fingerlings intoxicated with concentrated grades of chlorpyrifos.

\begin{tabular}{|c|c|c|c|c|}
\hline $\begin{array}{c}\text { Concentrations of } \\
\text { Chlorpyrifos }(\mu \mathrm{ml} / \mathrm{L})\end{array}$ & SLW ( $\mu \mathrm{m})$ & $\begin{array}{c}\text { Gill Morphometrics } \\
\text { SLL }(\mu \mathrm{m})\end{array}$ & $\mathrm{ILD}(\mu \mathrm{m})$ & $\operatorname{SLSA}(\mu \mathrm{m})^{2}$ \\
\hline 0.00 (Control) & $10.34 \pm 0.747^{\mathrm{a}}$ & $67.08 \pm 4.03^{\mathrm{a}}$ & $45.90 \pm 5.05^{\mathrm{a}}$ & $143.4 \pm 2.50^{\mathrm{a}}$ \\
\hline 6.25 & $15.50 \pm 1.32^{\mathrm{b}}$ & $57.73 \pm 2.72^{\mathrm{b}}$ & $40.24 \pm 2.56^{\mathrm{b}}$ & $124.71 \pm 4.56^{\mathrm{b}}$ \\
\hline 12.5 & $15.09 \pm 1.71^{\mathrm{b}}$ & $49.83 \pm 2.31^{\mathrm{c}}$ & $34.12 \pm 1.38^{c}$ & $112.68 \pm 8.66^{c}$ \\
\hline 25 & $17.23 \pm 0.05^{\mathrm{b}}$ & $47.29 \pm 5.69^{c}$ & $33.99 \pm 1.64^{c}$ & $91.16 \pm 3.92^{\mathrm{d}}$ \\
\hline 50 & $18.78 \pm 0.62^{\mathrm{b}}$ & $45.19 \pm 4.54^{\mathrm{c}}$ & $32.25 \pm 2.85^{c}$ & $87.22 \pm 5.72^{\mathrm{d}}$ \\
\hline 100 & $23.43 \pm 1.83^{c}$ & $42.50 \pm 5.35^{c}$ & $18.89 \pm 0.92^{\mathrm{d}}$ & $94.52 \pm 2.14^{\mathrm{d}}$ \\
\hline
\end{tabular}

Values with different superscript are significantly $(\mathrm{p}<0.05)$ different. SLW (Secondary Lamellar Width); SLL (Secondary Lamellar Length); ILD (Inter-lamellar Distance); SLSA (Secondary Lamellar Surface Area).

\subsection{SLL (Secondary Lamellar Length)}

Secondary lamellar length is the distance between the tip and the most distal point of the lamellae from the filament. The SLL of the gills of C.gariepinus fingerlings exposed to grades of chlorpyrifos showed strikingly significant reduction $(\mathrm{p}<0.05)$ with increasing concentration of chlorpyrifos. The SLL values were not significantly different $(p>0.05)$ between toxicant groups 25, 50 and $100 \mu \mathrm{ml} / \mathrm{L}$; though, statistically insignificant progressive decrease values were displayed.

\subsection{ILD (Inter-lamellar Distance)}

The distance between two secondary lamellae (The Inter-Lamellar Distance) of C. gariepinus exposed to chlorpyrifos showed significant progressive reduction $(\mathrm{p}<0.05)$ across toxicant dose concentrations when compared to the control. Interestingly, the highest toxicant dose showed a markedly reduced ILD relative to others.

\subsection{SLSA (Secondary Lamellar Surface Area)}

The surface area of secondary lamella covers the entire outer part of secondary lamella. The SLSA of the gill of C. gariepinus exposed to grades of chlorpyrifos displayed a significant dose dependant decrease $(\mathrm{p}<0.05)$ in SLSA when compared to the control. The SLSA values of the high toxicant dose groups $(25,50$ and $100 \mu \mathrm{ml} / \mathrm{L})$ were not significantly different $(\mathrm{p}>0.05)$ between the groups; but, an insignificant decrease $(\mathrm{p}>0.05)$ values were shown down the groups.

\section{Discussion}

This study has demonstrated that C.gariepinus exposed to grades of chlorpyrifos exhibited progressive marked histological damages (apical clubbing and rupturing of the secondary lamellae, gill filament vascular congestion, hypertrophy and hyperplasia of the lamellar epithelial cells) and related 
histomorphometric (secondary lamellar width, length surface area and interlamelar distance) changes in the gill parenchyma. The findings from this study are similar to available reports on histological and histio-morphometrical observations on the gills of fish exposed to related organic contaminants (ROSETY-RODRÍGUEZ, ORDOÑEZ, ROSETY et al., 2002; FANTA, RIOS, ROMÃO et al., 2003) and metals (OLIVEIRA RIBEIRO, PELLETIER, PFEIFFER et al., 2000; CERQUEIRA and FERNANDES, 2002; MARTINEZ, NAGAE, ZAIA et al., 2004).

The gill is the major organ for gaseous exchange and related important functions such as ionic and osmotic regulation (POLEKSIC and MITROVIC-TUTUNDZIC, 1994; ALAZEMI, LEWIS and ANDREWS, 1996; FERNANDES and MAZON, 2003). It has an extensive epithelial surface area that permits the aforementioned roles. Owing to this broad surface area, it remains the primary initial target of toxicity with eventual precipitation of cytological alterations in the gill parenchymal morphology (AU, 2004; REDDY and WASKALE, 2013). Therefore, the apical clubbing and rupturing of the secondary lamellae, gill filament vascular congestion, hypertrophy and hyperplasia of the lamellar epithelial cells induced by grades of chlorpyrifos concentrations in this study have implicative functional consequences on respiration. It is important to note that lesions like hypertrophic and hyperplastic lamellar epithelium end up in lamellar fusion and eventual blockage of water channel with a consequential deranged gaseous exchange in the lamellar epithelium (MACHADO and FANTA, 2003; CAMARGO and MARTINEZ, 2007; KUMAR, PRASAD, SRIVASTVA et al., 2010). The profile of the gill histopathology observed in this study seems to be dose-dependent with presence of severe damages to gill parenchyma at higher concentrations of the toxicant.

The possible underlining mechanism that might have been utilized by chlorpyrifos to induce the histological alterations observed in the gills; though not covered in the scope of this work, may be through the generation of reactive oxygen species which can successively culminate in oxidative stress that is characterised by the depletion of antioxidant enzymes [glutathione (GSH), catalase (CAT) and glutathione $S$ transferase (GST)] activities that are essentially needed for cellular antioxidant defence mechanisms (SAYEED, PARVEZ, PANDEY et al., 2003; DEB and SUCHISMITA, 2013). The findings on the gill's parenchymal alterations corroborate reports on similar changes in the gills of fishes exposed to metals (OLIVEIRA RIBEIRO, PELLETIER, PFEIFFER et al., 2000; CERQUEIRA and FERNANDES, 2002; MARTINEZ, NAGAE, ZAIA et al., 2004) and organic contaminants (ROSETY-RODRÍGUEZ et al., 2002; FANTA, RIOS, ROMÃO et al., 2003).

The parenchymal architectural composition and the morphometry of the gills are essential anatomical indices that collaborate to provide information relating to the fish mode of life and metabolic requirements (SATORA and ROMEK, 2010). The gill's epithelial surface area and its oxygen uptake capacity could be selectively influenced by certain gill dimensions that include length and abundance of gill filaments, the number of respiratory lamellae on the filaments, and lamellar bilateral surface area (WEGNER, SEPULVEDA, BULL et al., 2010). The observed inverse relationship in the gill secondary lamellar length and width (reduction and enlargement respectively) with increasing chlorpyrifos concentrations further confirms the underlining progressive epithelial cell hypertrophy or hyperplasia noticed in the histopathology of the gill parenchyma of this study. The peak of the epithelial hyperplasia was displayed by secondary lamellae epithelium of C.gariepinus dosed with highest toxicant concentration. Fundamentally, the various alterations in the length and width of the gill secondary lamellar could be suggestive of acute adaptive mechanism instituted to cope with the ensued toxicity from the toxicant (CAMARGO and MARTINEZ, 2007). Similarly, the surface area of secondary lamellar followed the pattern described for the length and width with strong evidence of dose dependant alterations. The increased surface area beyond normal especially with the highest concentrations of the toxicant is equally indicative of deleterious acute coping response to toxicant stress by the fish.

The interlamellar distance is a potential space between two neighbouring secondary lamellae where both oxygen uptake and gill resistance primarily take place (PATNAIK, HONGRAY, THERESIA et al., 2011; WEGNER, 2011). Against this background, the progressive dose dependent reduction in the interlamellar distance of the gills of chlorpyrifos-intoxicated C. gariepinus portends serious respiratory system collapse. As the space decreases, gaseous exchange between the lamellar epithelium and the environment reduces and may result in hypoxia more importantly with reduced oxygen movement into the epithelium. It is important to mention that this is the first report of histio-morphometric alterations in the gill of C.gariepinus exposed to grades of chlorpyrifos.

\section{Conclusion}

This study has shown that chlorpyrifos appears to be very toxic to fish and therefore, its use near fish farms or in areas close to aquatic environments should be discouraged.

\section{References}

AKINWOLE, AO. and FATUROTI, EO. Biological performance of African Catfish (Clarias gariepinus) cultured in recirculating system in Ibadan. Aquaculture Enginering, 2007, vol. 36, n. 1, p. 18-23. http://dx.doi.org/10.1016/j.aquaeng.2006.05.001.

ALAZEMI, BM., LEWIS, J. and ANDREWS, EB. Gill damage in the freshwater fish Gnathonemus petersii (Family: Mormyridae) exposed to selected pollutants: an ultra-structural study. Environmental Technology, 1996, vol. 17, n. 3, p. 225-238. http://dx.doi. org/10.1080/09593331708616381.

AU, DWT. The application of histocytopathological biomarkers in marine pollution monitoring: a review. Marine Pollution Bulletin, 2004, vol. 48, n. 9-10, p. 821. PMid:15111029. http://dx.doi. org/10.1016/j.marpolbul.2004.02.032.

BUTCHIRAM, MS., TILAK, KS. and RAJU, PW. Studies on histopathological changes in the gill, liver and kidney of Channa punctatus (Bloch) exposed to Alachlor. Journal of Environmental Biology, 2009, vol. 30, n. 2, p. 303-306. PMid:20121036.

CAMARGO, MMP. and MARTINEZ, CBR. Histopathology of gills, kidney and liver of a Neotropical fish caged in an urban stream. Neotropical Ichthyology, 2007, vol. 5, n. 3, p. 327-336. http://dx.doi. org/10.1590/S1679-62252007000300013.

CERQUEIRA, CCC. and FERNANDES, MN. Gill tissue recovery after copper exposure and blood parameter responses in the tropical fish Prochilodus scrofa. Ecotoxicology and Environmental Safety, 2002, 
vol. 52, n. 2, p. 83-91. PMid:12061823. http://dx.doi.org/10.1006/ eesa.2002.2164.

CHAKRABURTHY, G. and KONAR, SK. Chronic effects of sublethal levels of pesticides in fish. Proceeding National Academy of Science India, 1974, vol. 44, p. 241-246.

DEB, N., and SUCHISMITA, DAS. Chlorpyrifos toxicity in fish: a review. Current World Environment, 2013, vol. 8, n. 1, p. 77-84.

DEVI, Y. and MISHRA, A. Histopathological alterations in gill and liver anotomy of fresh water, air breathing fish channa punctatus after pesticide Hilban ${ }^{\circledast}$ (Chlorpyrifos) Treatment. Advanced Biomedical Research, 2013, vol. 4, n. 2, p. 57-62.

FANTA, E., RIOS, FS., ROMÃO, S., VIANNA, ACC. and FREIBERGER, S. Histopathology of the fish Corydoras paleatus contaminated with sublethal levels of organophosphorus in water and food. Ecotoxicology and Environmental Safety, 2003, vol. 54, n. 2, p. 119-130. PMid:12550089. http://dx.doi.org/10.1016/ S0147-6513(02)00044-1.

FERNANDES, MN. and MAZON, AF. Environmental pollution and fish gill morphology. In VAL, AL. and KAPOOR, BG. (Eds.). Fish adaptations. Enfield: Science Publishers, 2003. p. 203-231.

FOOD AND AGRICULTURE ORGANIZATION OF THE UNITED NATIONS - FAO. Fisheries and Aquaculture Department. Cultured Aquatic Species Information Programme. Clarias gariepinus. Rome: FAO, 2016. Available from: <ttp://www.fao.org/fishery/ culturedspecies/Clarias_gariepinus/en>. Access in: 20 July 2016.

HINTON, DE., BAUMANN, PC., GARDNER, GR., HAWKINS, WE., HENDRICKS, JD., MURCHELANO, RA. and OKIHIRO, MS. Histopathologic biomarkers. In HUGGET, R., KIMERLE, R., MEHRLE, P. and BERGMAN, H. (Eds.). Biomarkers biochemical, physiological and histological markers of anthropogenic stress. Boca Raton: Lewis Publishers, 1992. p. 155-195.

KARAMI, A., CHRISTIANUS, A., ISHAK, Z., COURTENAY, SC., SYED, MA., NOOR AZLINA, M. and NOORSHINAH, H. Effect of triploidization on juvenile African catfish (Clarias gariepinus). Aquaculture International, 2010, vol. 18, n. 5, p. 851-858. http:// dx.doi.org/10.1007/s10499-009-9307-x.

KUMAR, M., PRASAD, MR., SRIVASTVA, K., TRIPATHI, S. and SRIVASTVA, AK. Branchial histopathological study of Catfish Heteropneustes fossilis following exposure to purified neem extract, Azadirachtin. World Journal of Zoology, 2010, vol. 5, n. 4, p. 239-243.

MACHADO, M. and FANTA, E. Effects of the organophorous methyl parathion on the branchial epithelium of a freshwater fish Metynnis eoosevelti. Brazilian Archives of Biology and Technology, 2003, vol. 46, n. 3, p. 361-372. http://dx.doi.org/10.1590/S151689132003000300008 .

MAHMOUD, UM., MEKKAWY, IAA. and SAYED, AH. Ultraviolet radiation-A $(366 \mathrm{~nm})$ induced morphological and histological malformations during embryogenesis of Clarias gariepinus (Burchell, 1822). Journal of Photochemistry and Photobiology. B, Biology, 2009, vol. 95, n. 2, p. 117-128. PMid:19285878. http://dx.doi.org/10.1016/j. jphotobiol.2009.02.003.

MARTINEZ, CBR., NAGAE, MY., ZAIA, CTBV. and ZAIA, DAM. Morphological and physiological acute effects of lead in the neotropical fish Prochilodus lineatus. Brazilian Journal of Biology, 2004, vol. 64, n. 4, p. 797-807. PMid:15744420. http://dx.doi.org/10.1590/ S1519-69842004000500009.

MATHUR, DS., AGARWAL, HD. and RANA, PD. Histopathological changes in the liver and intestine of Rana cyanophyticlis (Sehne) induced by aldrin. Journal of Environmental Biology, 1981, vol. 2, p. 105-107.

NWANI, CD., IVOKE, N., OKECHUKWU, DU., ATAMA, C., ONYISHI, GC., ECHI, PC. and OGBONNA, SA. Investigation on acute toxicity and behavioral changes in a freshwater African catfish, Clariasgariepinus (Burchell, 1822), exposed to organophosphorous pesticide, Termifos ${ }^{\circledR}$. Pakistan Journal of Zoology, 2013, vol. 45, n. 4, p. 959-965.

NWANI, CD., UGWU, DO., OKEKE, OC., ONYISHI, GC., EKEH, FN., ATAMA, C. and ENEJE, LO. ATAMA, C and ENEJE, LO. Toxicity of the chlorpyrifos-based pesticide Termifos ${ }^{\circledR}$ : effects on behaviour and biochemical and haematological parameters of African catfish Clarias gariepinus. African Journal of Aquatic Science, 2013, vol. 38, n. 3, p. 255-262. http://dx.doi.org/10.2989/16085914 .2013 .780153 .

OKECHUKWU, EO., AUTA, J. and BALOGUN, JK. Effects of acute nominal doses of chlorpyrifos-ethyl on some haematological indices of African cat fish Clarias gariepinus Tengels. (2007). Journal of Fisheries International, 2007, vol. 2, n. 2, p. 190-194.

Oliveira Ribeiro, CA., PELletier, E., PFEIFFER, WC. and ROULEAU, C. Comparative uptake, bioaccumulation, and gill damages of inorganic mercury in tropical and nordic freshwater fish. Environmental Research, 2000, vol. 83, n. 3, p. 286-292. PMid:10944072. http://dx.doi.org/10.1006/enrs.2000.4056.

PATNAIK, BB., HONGRAY, HJ., THERESIA, M. and SELVANAYAGAM, M. Histopathology of gill, liver, muscle and brain of Cyprinus carpio communis L. exposed to sublethal concentration of lead and cadmium. African Journal of Biotechnology, 2011, vol. 10, n. 57, p. 12218-12223.

POLEKSIC, V. and MITROVIC-TUTUNDZIC, V. Fish gills as a monitor of sublethal and chronic effects of pollution. In MÜLLER, R. and LLOYD, R. (Eds.). Sublethal and Chronic effects of pollutants on freshwater fish. Oxford: Fishing News Books, 1994. p. 339-352.

REDDY, PB. and WASKALE, K. Using histopathology of fish as a protocol in the assessment of aquatic pollution. Journal of Environmental Research and Development, 2013, vol. 8, p. 372.

ROSETY-RODRÍGUEZ, M., ORDOÑEZ, FJ., ROSETY, M., ROSETY, JM., ROSETY, I., RIBELLES, A. and CARRASCO, C. Morpho-histochemical changes in the gills of turbot, Scophthalmus maximus L., induced by sodium dodecyl sulfate. Ecotoxicology and Environmental Safety, 2002, vol. 51, n. 3, p. 223-228. PMid:11971645. http://dx.doi.org/10.1006/eesa.2001.2148.

SAMAJDAR, I. and MANDAL, DK. Acute toxicity and impact of an organophosphate pesticide, chlorpyrifos on some haematological parameters of an Indian minor carp, Labeo bata (Hamilton 1822). International Journal of Environmental Sciences, 2015, vol. 6, n. 1, p. 106-113.

SANTOS, TCA., GOMES, V., PASSOS, MJACR., ROCHA, AJS. and SALAROLI, R. Histopathological alterations in gills of juvenile Florida pompano Trachinotus carolinus (Perciformes, Carangidae) following sublethal acute and chronic exposure to naphthalene. PanAmerican Journal of Aquatic Sciences, 2011, vol. 6, n. 2, p. 109-120.

SATORA, L. and ROMEK, M. Morphometry of the gill respiratory area in ruffe, Gymnocephalus cernuus (L.). Archives of Polish Fisheries, 2010, vol. 18, n. 1, p. 59-63. http://dx.doi.org/10.2478/v10086010-0007-y.

SAYEED, I., PARVEZ, S., PANDEY, S., BIN-HAFEEZ, B., HAQUE, R. and RAISUDDIN, S. Oxidative stress biomarkers of exposure to deltamethrin in freshwater fish Channa punctatus Bloch. Ecotoxicology and Environmental Safety, 2003, vol. 56, n. 2, p. 295-301. PMid:12927561. http://dx.doi.org/10.1016/S01476513(03)00009-5.

SHARBIDRE, AA. METKARI, V. and PATODE, P. Effect of methyl parathion and chlorpyrifos on certain biomarkers in various tissues of guppy fish, Poecilia reticulate. Pesticide Biochemistry and Physiology, 2011, vol. 10, p. 132-141. http://dx.doi.org/10.1016/j. pestbp.2011.09.002.

TEH, SJ., ADAMS, SM. and HINTON, DE. Histopathological biomarkers in feral freshwater fish populations exposed to different 
types of contaminant stress. Aquatic Toxicology, 1997, vol. 37, n. 1, p. 51-70. http://dx.doi.org/10.1016/S0166-445X(96)00808-9.

THOPHON, S., KRUATRACHUE, M., UPATHAM, ES., POKETHITIYOOK, P., SAHAPHONG, S. and JARITKHUAN, S. Histopathological alterations of white seabass, Lates calcarifer in acute and subchronic cadmium exposure. Environmental Pollution, 2003, vol. 121, n. 3, p. 307-320. PMid:12685759. http://dx.doi. org/10.1016/S0269-7491(02)00270-1.

U.S. ENVIRONMENTAL PROTECTION AGENCY - EPA. Disciplinary review ecological effects profile. Washington: US Environmental Protection Agency, Office of Pesticide Programs, 1985. p. 10.

VIJAYALAKSHMI, S. and TILAK, KS. Effect of pesticides on the gill morphology of Labeo rohita. Journal of Ecotoxicology and Environmental Monitoring, 1996, vol. 6, p. 59-64.
WATTS, M. Chlorpyrifos. Panang: Pesticide Action Network Asia and the Pacific, 2013. p. 1-68.

WEGNER, NC. Gill respiratory morphometrics. In: ARRELL, AP. (Ed.). Encyclopedia of fish physiology: from genome to environment. San Diego: Academic Press, 2011. p. 803-811. vol. 2.

WEGNER, NC., SEPULVEDA, CA., BULL, KB. and GRAHAM, J. Gill morphometrics in relation to gas transfer and ram ventilation in high-energy demand Teleosts: Scombrids and Billfishes. Journal of Morphology, 2010, vol. 271, n. 1, p. 36-49. PMid:19658098. http:// dx.doi.org/10.1002/jmor.10777. 